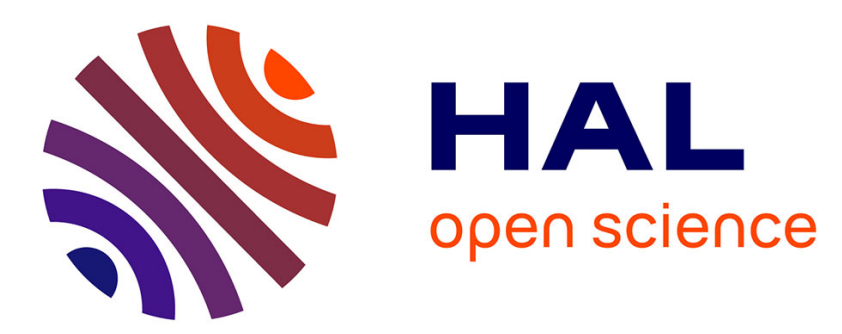

\title{
Tracking subducted ridges through intermediate-depth seismicity in the Vanuatu subduction zone
}

Christian Baillard, Wayne C. Crawford, Valérie Ballu, Bernard Pelletier, Esline Garaebiti

\section{- To cite this version:}

Christian Baillard, Wayne C. Crawford, Valérie Ballu, Bernard Pelletier, Esline Garaebiti. Tracking subducted ridges through intermediate-depth seismicity in the Vanuatu subduction zone. Geology, 2018, 46 (9), pp.767-770. 10.1130/G45010.1 . hal-03009620

\section{HAL Id: hal-03009620 \\ https://hal.science/hal-03009620}

Submitted on 29 Dec 2020

HAL is a multi-disciplinary open access archive for the deposit and dissemination of scientific research documents, whether they are published or not. The documents may come from teaching and research institutions in France or abroad, or from public or private research centers.
L'archive ouverte pluridisciplinaire HAL, est destinée au dépôt et à la diffusion de documents scientifiques de niveau recherche, publiés ou non, émanant des établissements d'enseignement et de recherche français ou étrangers, des laboratoires publics ou privés. 


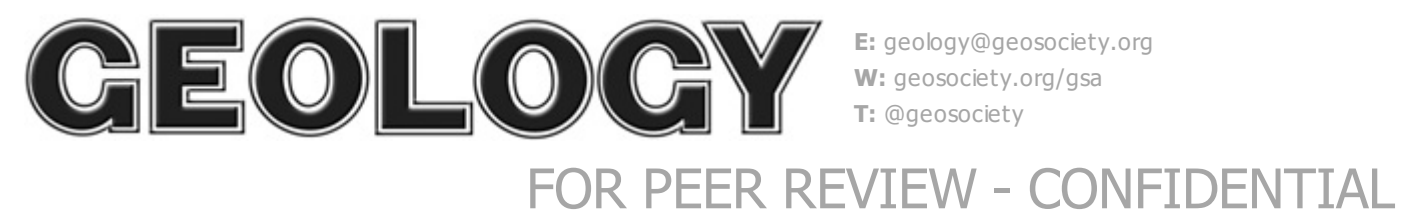

\section{Tracking subducted ridges through intermediate-depth seismicity in the Vanuatu subduction zone}

Tracking no: G45010R

\section{Authors:}

Christian Baillard (University of Washington School of Oceanography), Wayne Crawford (Institut de Physique du Globe de Paris), Valérie Ballu (Littoral ENvironnement et Sociétés), Bernard Pelletier (Institut pour la Recherche et le Développement), and Esline Garaebiti (Geohazards Section, Vanuatu Meteorology and Geohazards Department)

\section{Abstract:}

The distribution of intermediate-depth seismicity beneath the Vanuatu archipelago includes several seismic clusters/alignments and gaps, including a remarkable $200 \times 150 \mathrm{~km}$ gap beneath central Vanuatu. We show that a zone of enhanced seismicity beneath this gap corresponds to the most likely trace of the subducted D'Entrecasteaux Ridge (DER) and that another region of aligned seismicity to the south may correspond to another significant, now disappeared ridge. We suggest that regions of aligned intermediate-depth seismicity beneath Vanuatu are traces of subducted oceanic features on the downgoing plate, probably caused by enhanced hydration beneath them prior to subduction. The seismic gap above the DER trace, previously interpreted as a tear in the slab, may instead be a region of reduced hydration due to thick/unfractured input crust, low bending of this crust before subduction and/or greater slab residence time at shallower subducted depths, the latter two being directly related to DER collision. We propose that an uneven distribution of intermediate-depth seismicity at subduction zones may provide a window to the history and effects of subducted oceanic features. 
1 Tracking subducted ridges through intermediate-depth seismicity in the Vanuatu

2 subduction zone

3 Christian Baillard ${ }^{1}$, Wayne C. Crawford ${ }^{2}$, Valérie Ballu ${ }^{3}$, Bernard Pelletier ${ }^{4}$ and Esline 4 Garaebiti $^{5}$

$5{ }^{1}$ School of Oceanography, University of Washington, 1503 NE Boat St, 98105 Seattle, WA, US,

6 baillard@uw.edu

$7 \quad{ }^{2}$ Institut de Physique du Globe de Paris, CNRS UMR 7154, Université Paris Diderot, 1 rue Jussieu, 875238 Paris cedex 05, France, crawford@ipgp.fr

$9{ }^{3}$ Littoral ENvironnement et Sociétés (LIENSS), CNRS UMR 7266, Université de La Rochelle, 2 rue 10 Olympe de Gouges, 17000 La Rochelle, France, valerie.ballu@univ-lr.fr

$11 \quad{ }^{4}$ Institut pour la Recherche et le Développement, Nouméa, New Caledonia, bernard.pelletier@ird.fr

$12{ }^{5}$ Geohazards Section, Vanuatu Meteorology and Geohazards Department, PMB 9054, Lini Highway,

13 Number 2, Port Vila, Vanuatu, gesline@vanuatu.gov.vu 
ABSTRACT

The distribution of intermediate-depth seismicity beneath the Vanuatu archipelago includes several seismic clusters/alignments and gaps, including a remarkable $200 \times 150 \mathrm{~km}$ gap beneath central Vanuatu. We show that a zone of enhanced seismicity beneath this gap corresponds to the most likely trace of the subducted D'Entrecasteaux Ridge (DER) and that another region of aligned seismicity to the south may correspond to another significant, now disappeared ridge. We suggest that regions of aligned intermediate-depth seismicity beneath Vanuatu are traces of subducted oceanic features on the downgoing plate, probably caused by enhanced hydration beneath them prior to subduction. The seismic gap above the DER trace, previously interpreted as a tear in the slab, may instead be a region of reduced hydration due to thick/unfractured input crust, low bending of this crust before subduction and/or greater slab residence time at shallower subducted depths, the latter two being directly related to DER collision. We propose that an uneven distribution of intermediate-depth seismicity at subduction zones may provide a window to the history and effects of subducted oceanic features.

\section{INTRODUCTION}

The $\sim 500 \mathrm{~km}$ long Vanuatu archipelago overlies one of world's most seismically active subduction zones, with an average of one magnitude 7+ earthquake recorded per year since 1972 (National Earthquake Information Center). The present-day convergence rate between the Vanuatu islands and the subducting Australian plate varies from $120 \mathrm{~mm} / \mathrm{yr}$ in the south to $160 \mathrm{~mm} / \mathrm{yr}$ in the north, but slows to $35 \mathrm{~mm} / \mathrm{yr}$ in the center (Fig. 1) (Calmant et al., 2003; Bergeot et al., 2009). This slowing, and the existence of uplift sequences affecting part of the forearc islands (up to $6 \mathrm{~mm} / \mathrm{yr}$ over the past $150 \mathrm{Ka}$ ) (Taylor et al., 2005), can be linked to the subduction of a large and irregular bathymetric feature: the D'Entrecasteaux Ridge (DER). The DER, which extends back along the Australian Plate to New Caledonia, appears to have entered into subduction 2-3 $\mathrm{Ma}$ at the Epi reentrant, 160 km to the south (Fig. 1); (Greene et al., 1994; Meffre and Crawford, 2001). 
Intermediate depth seismicity $(50-300 \mathrm{~km}$ depth) in the Vanuatu region is mostly constrained by the global seismic network. Shallow seismicity $(<50 \mathrm{~km}$ depth) is constrained by a temporary network that focused on the central forearc in 2008-9 (Baillard et al., 2015). Intermediatedepth seismicity in the Vanuatu region falls on or near a Wadati-Benioff zone corresponding to the subducting slab and is highly variable along-strike, with several clusters or alignments of intense seismicity as well as several regions almost completely lacking seismicity (Fig. 2A). Most authors associate variations in intermediate-depth seismicity with how much water is subducted and the depth and temperatures at which dehydration embrittlement occurs (e.g., Hacker et al., 2003; Yamasaki and Seno, 2003; Omori et al., 2004; Milsch and Scholz, 2005) and the maximum depth of this seismicity is generally greater in colder subducting slabs than in warmer ones (Kirby et al., 1996; Omori et al., 2004; Abers et al., 2013). Most of these observations and models are derived from differences between subduction zones, but variations are also observed within some subduction zones (e.g., Eberhart-Phillips et al. (2013) for New Zealand and Shillington et al. (2015) for Alaska), where they are generally explained as local differences in hydration prior to subduction associated with differences in plate fabric orientation with respect to the trench axis.

In this study we show that a region of enhanced seismicity in Central Vanuatu (Area C in Fig. 2A) corresponds to the most likely trace of the subducted DER. We suggest that the enhanced seismicity results from dehydration processes of the oceanic crust and upper mantle beneath the DER and that the aseismic region above it could be caused by lower hydration of surrounding slab. Other alignments of intermediate-depth seismicity beneath Vanuatu could also correspond to subducted bathymetric features, including one just north of the DER trace (Area N in Fig. 2A) and another 400 $\mathrm{km}$ to the south (Area S in Fig. 2A), in front of a possible subduction front reentrant (Figs. 1 and 2B). The traces of these features could provide a means for determining the past geometry and effects of subduction and collisions at the Vanuatu and other subduction zones. 
Regions of enhanced intermediate-depth seismicity are often associated with local 67 dehydration of minerals within the subducting slab as it descends (Eberhart-Phillips et al., 2013; Shillington et al., 2015; Paulatto et al., 2017). The northern portion of the DER, composed of Eocene magmas, can be described as a fossil transform fault or subduction zone that links up with the fossil

New-Caledonia subduction zone, which was mainly active during the Eocene. The southern portion of the DER, including the Bougainville seamount (Fig. 4), can be considered as a Eocene volcanic arc (Maillet et al., 1983; Collot et al., 1994; Schellart et al., 2006; Mortimer et al., 2014). The history and nature of the DER indicate a highly fractured system, with deep faults allowing enhanced hydration to oceanic mantle depths as has been observed at other subduction zones (e.g., Lefeldt \& Grevemeyer, 2008; Lefeldt et al., 2009; Ivandic et al., 2010; Fujie et al., 2013; Shillington et al., 2015). The relatively high thermal parameter of the Australian plate at intermediate depth (> 2400: Text T1 and Baillard et al., 2015) allows hydrous minerals to be carried deep in the mantle before dehydration.

We estimated the position of the subducted DER under the Vanuatu arc by fitting a curve on the descending slab between the current point of collision and the point of collision 2-3 Ma projected along the slab (Fig. S1 and Text T2). The position and the termination of this projected ridge correspond to a region of enhanced intermediate-depth seismicity beneath the slab's biggest seismic gap (Figs. 2A, 3 and S2). The trace of this enhanced seismicity extends from 100 to $200 \mathrm{~km}$ depth, indicating upper oceanic mantle deserpentinization: oceanic crust eclogitization is generally limited to < $150 \mathrm{~km}$ depth (e.g., Hacker et al., 2003b; Maruyama and Okamoto, 2007) and the apex of this process is estimated at $75 \mathrm{~km}$ depth in Vanuatu (Baillard et al., 2015), whereas the apex of oceanic mantle deserpentinization is estimated at $170-220 \mathrm{~km}$ for Vanuatu (Syracuse et al., 2010). Most intermediate-depth Vanuatu earthquakes have N-S (Trench-parallel) strike directions, suggesting that they are driven by slab pull forces (Christova et al., 2004), but some events along the DER trace have E-W orientations (Fig. S3), consistent with the orientation of the DER horsts and grabens (Maillet et al., 1983).

A $200 \mathrm{~km}$ wide "gap" in intermediate-depth seismicity from 50-200 km depth lies just above and south of the aforementioned seismicity alignment (Area C in Fig. 2). The gap was previously 
interpreted to be the signature of the subducted DER itself (Marthelot et al., 1985) or a tear in the

94 subducting slab (Prévot et al., 1991; Chatelain et al., 1992) but, based on more recent understanding 95 of the controls on intermediate-depth seismicity, we propose that it is a low hydration region. This low hydration could be pre-existing or driven by the DER collision. The pre-existing North Loyalty Basin is composed of a $\sim 15 \mathrm{~km}$ thick, relatively unfractured oceanic crust (Pontoise et al., 1980; Maillet et al., 1983), which may be relatively un-hydrated. The DER collision tends to flatten the entry of the adjacent plate into subduction and slow the convergence rate, reducing the bending force on that plate before subduction and increasing the time that the plate would spend at shallow depths. This reduced bending at shallow depths could limit the penetration of faults and therefore the hydration of the oceanic lower crust and upper mantle, while the long time at shallow subduction depths would allow more time for eclogitization reactions in the crust to run their course before the slab descends to intermediate-earthquake depths. If these last two "active" processes are indeed important in reducing slab hydration, then the shift of the gap to the south with increasing depth suggests that the slowed convergence currently observed around south Santo island is a long-term feature which has migrated north with the DER collision zone.

\section{OTHER LINEATIONS OF INTERMEDIATE-DEPTH SEISMICITY}

Other lineations of intermediate-depth seismicity beneath Vanuatu may also be linked to subducted oceanic features (Fig. 2A). One such feature starts just north of the DER lineation at approximately $100 \mathrm{~km}$ depth and extends northward to $\sim 200 \mathrm{~km}$ depth (Area $\mathrm{N}$ in Fig. 2A). It is, like the DER trace, oblique to the convergence direction. This feature could be linked to a subducted portion of the West Torres Plateau (Fig. 1), which is currently colliding offshore north Santo island, causing the uplift of the Torres islands (Taylor et al., 1985). Similar to the DER trace, there is a secondary cluster of events with E-W strike, suggesting the possible reactivation of pre-existing faults (Fig. S3). Intermediate-depth seismicity also appears to be slightly reduced above this lineation. 
118 Another strong lineation of intermediate-depth earthquakes is observed near Tanna and Erromango

119 islands (Area S in Fig. 2A). This feature does not correlate with any current seamounts or ridges on

120 the subducting plate, but a morphologic feature on the trench just southwest of Tanna (Figs. 1 and 2B)

121 could be a reentrant caused by an ancient collision front.

\section{DISCUSSION}

123 Lineations in intermediate-depth seismicity may reveal the subduction history at other subduction 124 zones where strongly hydrated oceanic features enter into subduction. For example, Nakajima and 125 Hasegawa (2006) observed a lineation of seismicity that could be linked to a subducted fracture zone. 126 Other examples include a lineation of intermediate-depth earthquakes beneath Ecuador, which 127 appears to correlate with the subducted prolongation of the Grijalva Fracture Zone (Fig. S4) and 128 similar correlations beneath Peru with the Nazca fracture zone and beneath Tonga-Kermadec with the 129 Louisville Ridge (Figs. S5-6).

130 Variations in intermediate-depth seismicity have been also observed to correlate with variations in 131 surface volcanic rheology (Eberhart-Phillips et al., 2013). Vanuatu intermediate-depth earthquake 132 lineations appear to correlate with along-arc variations in isotopic ratios (Fig. S7), high Ba/La and $133 \mathrm{~Pb} / \mathrm{Nd}$ ratios are observed directly above subducted features, indicating possible enrichment by slab 134 derived fluids (Peate et al., 1997) released predominantly in the vicinity of the subducted features.

135 Finer-scale isotope measurements are needed to validate this hypothesis.

136 Where intermediate depth earthquakes do not correlate with present-day topographic features on the 137 subducting plate, they may help to identify subducted features with no remaining seafloor trace. Both 138 the enhanced seismicity and any seismic gaps around them could be studied to determine if there was

139 significant blocking or slowing of convergence when the feature subducted. Deducing the past history

140 of oceanic features could help both kinematic constructions of local plate history and our 141 understanding of the role of subducted oceanic features on arc magmatism.

\section{CONCLUSION}


143 Lineations and gaps in intermediate-depth seismicity beneath the Vanuatu arc appear to be associated

144 with deeply fractured subducted features. The clearest correlation is observed with the

145 D'Entrecasteaux ridge, whose most likely continuation beneath the Vanuatu arc corresponds to a 146 region of enhanced intermediate-depth seismicity within the subducted slab (Fig. 4). A large region

147 of reduced intermediate-depth seismicity above this zone may result from reduced oceanic/mantle

148 hydration there, either as an effect of pre-existing thick oceanic crust of the North Loyalty Basin or

149 because of processes related to reduced bending behind the DER collision zone: 1) reduced deep

150 hydration of pre-subducted slab through reduced bending and fault penetration and 2) increased

151 dehydration of subducted oceanic crust at shallow depths because of a longer residence there.

152 Other lineations that may be associated with subducted features include 1) an oblique zone just north

153 of the DER extension, which may correspond to the West Torres Plateau going back to a time when it

154 was closer to the location of the Torres forearc islands; 2) a dip-parallel zone beneath Tanna and

155 Erromango islands, which may be associated with a completely subducted hydrated ridge.

156 Such lineations may provide a picture of past shallow subduction zone features, which could be used

157 to model and/or explain past changes in seismicity and plate motions.

\section{ACKNOWLEDGMENTS}

160 We thank the Vanuatu Government and the Vanuatu Geohazards Observatory for their aid and

161 support. We also thank IPGP and the French Government for their support through the Ph.D. 162 Scholarship. 
164 Abers, G.A., Nakajima, J., van Keken, P.E., Kita, S., and Hacker, B.R., 2013, Thermal-petrological 165 controls on the location of earthquakes within subducting plates: Earth and Planetary Science Letters, v. 369-370, p. 178-187, doi: 10.1016/j.epsl.2013.03.022.

Baillard, C., Crawford, W.C., Ballu, V., Régnier, M., Pelletier, B., and Garaebiti, E., 2015, Seismicity and shallow slab geometry in the central Vanuatu subduction zone: Journal of Geophysical Research: Solid Earth, v. 120, no. 8, p. 5606-5623, doi: 10.1002/2014JB011853.

Bergeot, N., Bouin, M.N., Diament, M., Pelletier, B., Régnier, M., Calmant, S., and Ballu, V., 2009, Horizontal and vertical interseismic velocity fields in the Vanuatu subduction zone from GPS measurements: Evidence for a central Vanuatu locked zone: Journal of Geophysical Research, v.

Calmant, S., Pelletier, B., Lebellegard, P., Bevis, M., Taylor, F.W., and Phillips, D.A., 2003, New insights on the tectonics along the New Hebrides subduction zone based on GPS results: Journal

Christova, C., Scholz, C.H., and Kao, H., 2004, Stress field in the Vanuatu (New Hebrides) Wadati Benioff zone inferred by inversion of earthquake focal mechanisms: Journal of Geodynamics, v.

Collot, J., Greene, H., Fisher, M., and Geist, E.L., 1994, Tectonic accretion and deformation of the accretionary wedge in the North d'Entrecasteaux ridge-New Hebrides Island arc collision zone: evidence from multichannel seismic reflection profiles and leg 134 results: Proceedings of the Ocean Drilling Program, Scientific Results, v. 134. 

subducting plate seismicity and mantle wedge attenuation related to fluid release beneath the North Island, New Zealand: Physics of the Earth and Planetary Interiors, v. 225, p. 12-27, doi: 10.1016/j.pepi.2013.10.002.

Fujie, G., Kodaira, S., Yamashita, M., Sato, T., Takahashi, T., and Takahashi, N., 2013, Systematic changes in the incoming plate structure at the Kuril trench: Geophysical Research Letters, v. 40, no. 1, p. 88-93, doi: 10.1029/2012GL054340.

Greene, H., Collot, J., Fisher, M.A., and Crawford, A., 1994, NEOGENE TECTONIC EVOLUTION OF THE NEW HEBRIDES ISLAND ARC : A REVIEW INCORPORATING ODP DRILLING RESULTS: Proceedings of the Ocean Drilling Program, Scientific Results, v. 134.

Hacker, B.R., Peacock, S.M., Abers, G.A., and Holloway, S.D., 2003, Subduction factory 2. Are intermediate-depth earthquakes in subducting slabs linked to metamorphic dehydration reactions? Journal of Geophysical Research: Solid Earth, v. 108, no. B1, p. 2030, doi: 10.1029/2001JB001129.

Ivandic, M., Grevemeyer, I., Bialas, J., and Petersen, C.J., 2010, Serpentinization in the trench-outer rise region offshore of Nicaragua: constraints from seismic refraction and wide-angle data: Geophysical Journal International, v. 180, no. 3, p. 1253-1264, doi: 10.1111/j.1365246X.2009.04474.x.

Kirby, S., Engdahl, R., and Denlinger, R., 1996, Intermediate-depth intraslab earthquakes and arc volcanism as physical expressions of crustal and uppermost mantle metamorphism in subducting slabs: Geophysical Monograph Series, p. 195-214, doi: 10.1029/GM096p0195.

Lefeldt, M., and Grevemeyer, I., 2008, Centroid depth and mechanism of trench-outer rise earthquakes: Geophysical Journal International, v. 172, no. 1, p. 240-251, doi: 10.1111/j.1365246X.2007.03616.x.

Lefeldt, M., Grevemeyer, I., and Goßler, J., 2009, Intraplate seismicity and related mantle hydration at the Nicaraguan trench outer rise: Geophysical Journal,. 
Maillet, P., Monzier, M., Selo, M., and Storzer, D., 1983, The D’Entrecasteaux Zone (Southwest Pacific). A petrological and geochronological reappraisal: Marine Geology, v. 53, no. 3, p. 179197, doi: 10.1016/0025-3227(83)90073-7.

Marthelot, J., Chatelain, J., Isacks, B., Cardwell, R., and Coudert, E., 1985, Seismicity and attenuation in the central Vanuatu (New Hebrides) islands : a new interpretation of the effect of subduction of the D'Entrecasteaux fracture zone: Journal of Geophysical Research, v. 90, p. 8641-8650.

Maruyama, S., and Okamoto, K., 2007, Water transportation from the subducting slab into the mantle transition zone: Gondwana Research, v. 11, no. 1-2, p. 148-165, doi: 10.1016/j.gr.2006.06.001.

Meffre, S., and Crawford, A.J., 2001, Collision tectonics in the New Hebrides arc (Vanuatu): The Island Arc, v. 10, no. 1, p. 33-50, doi: 10.1046/j.1440-1738.2001.00292.x.

Milsch, H.H., and Scholz, C.H., 2005, Dehydration-induced weakening and fault slip in gypsum: Implications for the faulting process at intermediate depth in subduction zones: Journal of Geophysical Research: Solid Earth, v. 110, no. B4, p. 1-16, doi: 10.1029/2004JB003324.

Mortimer, N., Gans, P.B., Palin, J.M., Herzer, R.H., Pelletier, B., and Monzier, M., 2014, Eocene and oligocene basins and ridges of the coral sea-new caledonia region: Tectonic link between melanesia, fiji, and zealandia: Tectonics, v. 33, no. 7, p. 1386-1407, doi: 10.1002/2014TC003598.

Nakajima, J., and Hasegawa, A., 2006, Anomalous low-velocity zone and linear alignment of seismicity along it in the subducted Pacific slab beneath Kanto, Japan: Reactivation of subducted fracture zone? Geophysical Research Letters, v. 33, no. 16, p. L16309, doi: 10.1029/2006GL026773.

Omori, S., Komabayashi, T., and Maruyama, S., 2004, Dehydration and earthquakes in the subducting slab: empirical link in intermediate and deep seismic zones: Physics of the Earth and Planetary Interiors, v. 146, no. 1-2, p. 297-311, doi: 10.1016/j.pepi.2003.08.014.

Paulatto, M., Laigle, M., Galve, A., Charvis, P., Sapin, M., Bayrakci, G., Evain, M., and Kopp, H., 

Communications, v. 8, no. May, p. 15980, doi: 10.1038/ncomms 15980.

Peate, D.W., Pearce, J. a., Hawkesworth, C.J., Colley, H., Edwards, C.M.H., and Hirose, K., 1997, Geochemical Variations in Vanuatu Arc Lavas: the Role of Subducted Material and a Variable

Pontoise, B., Latham, G., Daniel, J., Dupont, J., and Ibrahim, B., 1980, Seismic refraction studies in the New Hebrides and Tonga area: UN ESCAP, CCOP/SOPAC Tech. Bull, p. 47-58.

Prévot, R., Roecker, S.W., Isacks, B.L., and Chatelain, J.L., 1991, Mapping of low P wave velocity structures in the subducting plate of the central New Hebrides, southwest Pacific: Journal of Geophysical Research: Solid Earth, v. 96, no. B12, p. 19825-19842, doi: 10.1029/91JB01837.

Schellart, W.P., Lister, G.S., and Toy, V.G., 2006, A Late Cretaceous and Cenozoic reconstruction of the Southwest Pacific region: Tectonics controlled by subduction and slab rollback processes:

Shillington, D.J., Bécel, A., Nedimović, M.R., Kuehn, H., Webb, S.C., Abers, G. a., Keranen, K.M., Earth-Science Reviews, v. 76, no. 3-4, p. 191-233, doi: 10.1016/j.earscirev.2006.01.002.

Syracuse, E.M., van Keken, P.E., and Abers, G. a., 2010, The global range of subduction zone thermal models: Physics of the Earth and Planetary Interiors, v. 183, no. 1-2, p. 73-90, doi:

Taylor, F.W., Jouannic, C., and Bloom, A.L., 1985, Quaternary Uplift of the Torres Islands, Northern New Hebrides Frontal Arc: Comparison with Santo and Malekula Islands, Central New 10.1016/j.pepi.2010.02.004. 

Beck, J.W., Phillips, D. a., Cabioch, G., and Recy, J., 2005, Rapid forearc uplift and subsidence caused by impinging bathymetric features: Examples from the New Hebrides and Solomon arcs: Tectonics, v. 24, no. 6, p. n/a-n/a, doi: 10.1029/2004TC001650.

266 Yamasaki, T., and Seno, T., 2003, Double seismic zone and dehydration embrittlement of the subducting slab: Journal of Geophysical Research: Solid Earth, v. 108, no. B4, p. 2212, doi: 10.1029/2002JB001918.

269

270 
272 Figure 1. The Vanuatu archipelago. Main islands with active volcanoes are filled in red. White arrows

273 indicate the interseismic convergence rates along the subduction front (Calmant et al., 2003; Bergeot

274 et al., 2009). Contour with triangles shows subduction front and solid black contour is the $3500 \mathrm{~m}$

275 depth contour on the island arc side of the subduction front. White rounded boxes surround the Epi

276 and Tanna reentrants. The tilted black box shows the bounds used for the along-arc view in Fig 2. AP:

277 Australian Plate; NFB: North Fiji Basin; DER: D’Entrecasteaux Ridge; NLoB: North Loyalty Basin.

278 Figure 2. Along-arc view of Vanuatu seismicity and reentrants. Positions of active volcanoes are

279 indicated by red triangles, other major islands by black bars. A) Earthquakes since 1972 (circles) as a

280 function of depth. "Seismic gap" is outlined by polygons with dashed borders and seismicity

281 clusters/alignments are outlined by rounded boxes. B) Distance between the subduction front and the

$2823500 \mathrm{~m}$ depth contour shown in Fig.1. The Tanna and Epi reentrants are labeled.

283 Figure 3. Seismicity from global and 2008-9 local networks and the projected subducted DER. Red

284 line is the constant curvature model of the DER shown in Fig. S1. Dashed lines are the limits for

285 different long-term convergence rates and DER shapes.

286 Figure 4. Conceptual figure showing how the distribution of intermediate-depth earthquakes (red 287 stars) relates to subducted topographic features. The dense fracture systems associated with these 288 features favor hydration of oceanic crust and upper mantle prior to subduction. Hydrous minerals are 289 then progressively dehydrated with increasing depth, triggering intermediate-depth earthquakes.

290 Dehydration progresses from the oceanic crust at lower depths (eclogitization) to the oceanic upper 291 mantle at greater depths (deserpentinization). The region of white rounded shapes indicates the 292 seismogenic zone. SB: Sabine Bank; BS: Bougainville Seamount; Gbr: Gabbro; Bsh: Blue Schist; 293 Prd: Peridotite; Srp: Serpentine 
Figure 2

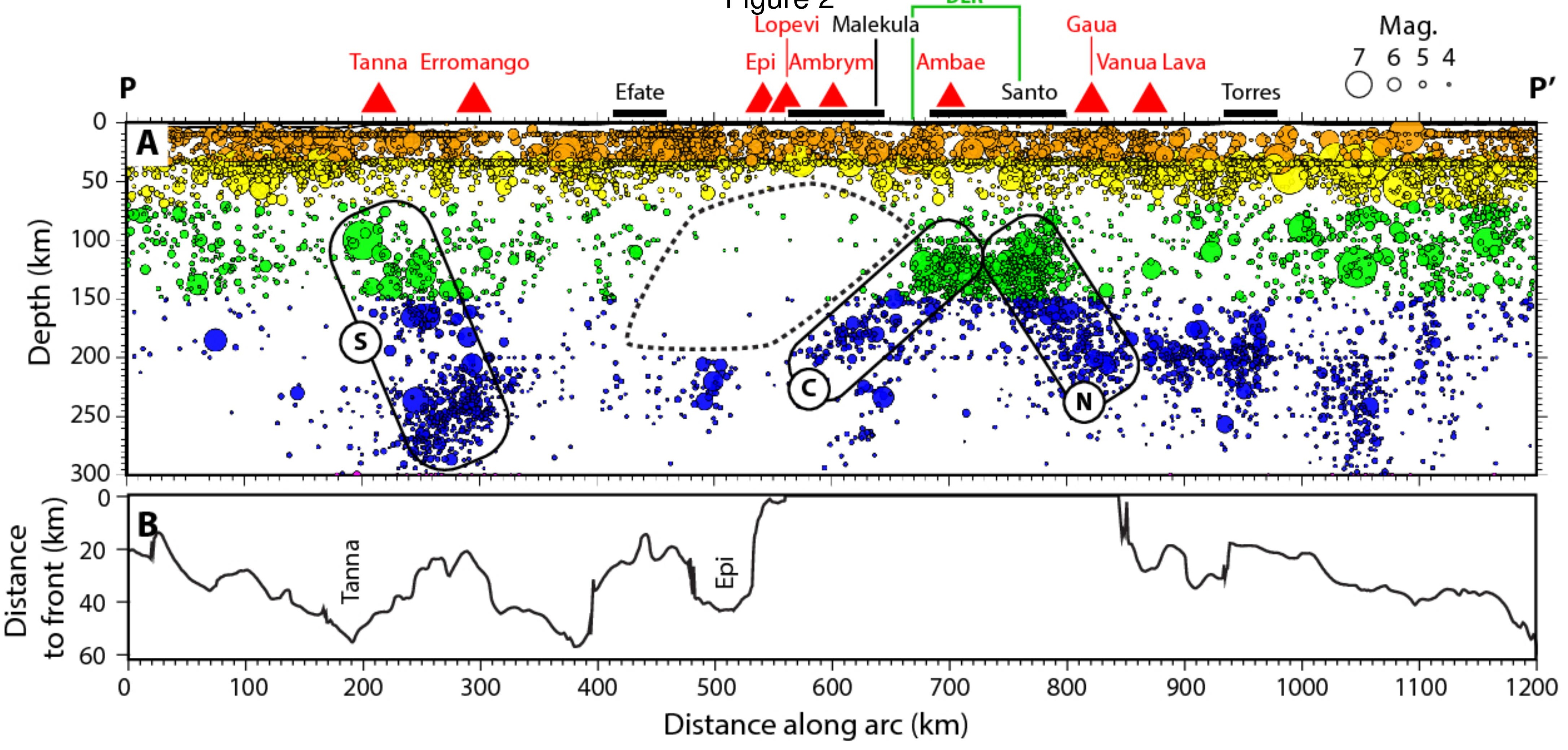




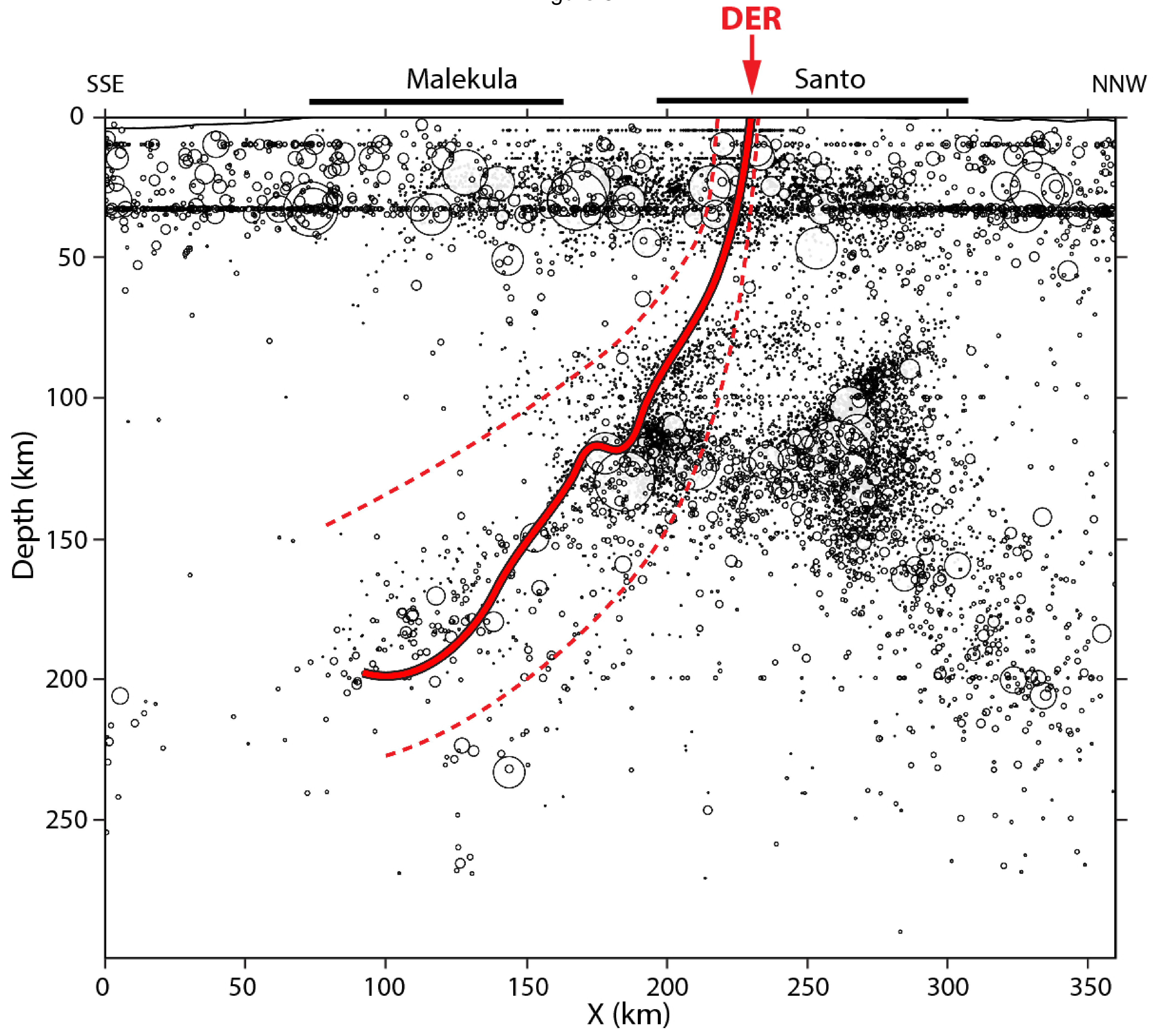


Figure 4

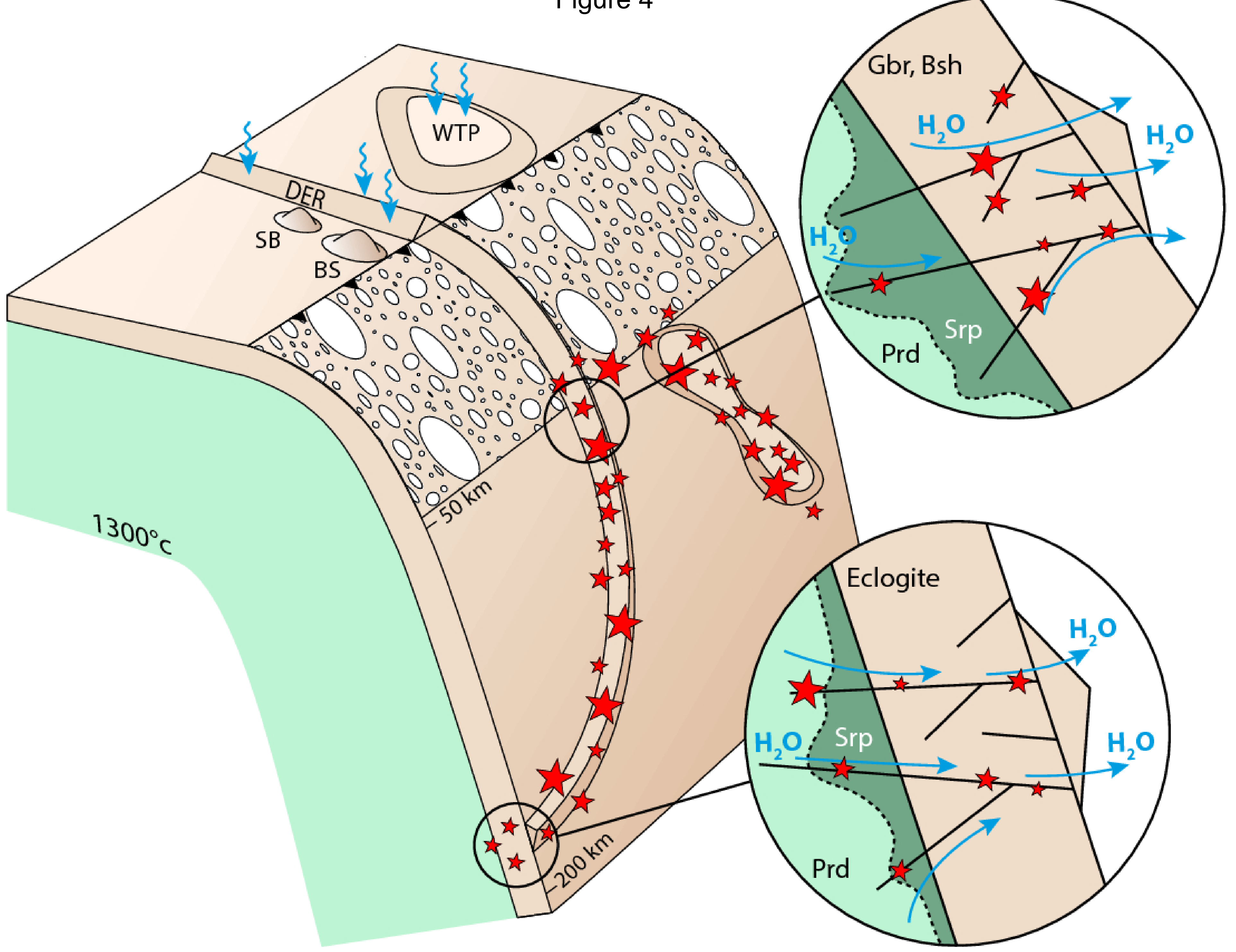

